\title{
The Concept of Hadith Maudhü, and Its Contextualization in Information Management in the Digital Era
}

\section{Fajar Rachmadhani}

Universitas Muhammadiyah Yogyakarta

fajarrachmadhani@umy.ac.id

DOI: http://dx.doi.org/10.29240/alquds.v3i2.1009

Submitted: 2019-08-16 | Revised: 2019-10-18 |Accepted: 2019-10-29

\begin{abstract}
The purpose of this research is to discuss the role of ulumul hadith studies in responding to contemporary problems, specifically to discuss the concept of hadith maudhu $\bar{u}$, as well as its relevance and contextualization in helping and responding to news or information in the digital era, especially in dealing with hoaxes, where there are similarities of motives, indicators, and solutions to eradicate them. The results of this research are expected to be useful and contribute both practically and theoretically. The practical benefits of this research are expected to be able to provide encouragement and motivation to Muslims to always study vast treasures (khazanah) of Islamic science, especially in the ulumul hadith studies, so that a moderate Islamic society is realized and always prioritizes caution and clarification in accepting and disseminating news and information in this digital era. The type of this research included qualitative research, and its primary sources were the principles ulumul hadith books which discussed about hadith maudhu. Additionally, its secondary sources were the information contained in journals, websites, and others. This research used content analysis approach. This method was used to conclude efforts to bring up the characteristics of messages carried out objectively and systematically.
\end{abstract}

Keywords: Hadith Maudhū, Information Management, Digital Era

Abstrak. Tujuan dari penelitian ini adalah untuk membahas peranan studi ulumul hadis
dalam merenspon problematika kontemporer, khususnya pembahasan terkait konsep
hadits maudhü serta relevansinya dan kontekstualisasinya dalam mensikapi serta
mengelola berita atau informasi yang beredar di era digital saat ini, terlebih yang
berkaitan dengan maraknya penyebaran hoax di media sosial, dimana antara hadis
maudhü dan hoax ini memiliki kesamaan motif, indikator, dan solusi dalam
pemberantasannya. Hasil penelitian ini diharapkan bermanfaat dan memberikan
kontribusi baik secara praktis maupun teoritis. Manfaat praktis dari penelitian ini
diharapkan dapat memberikan dorongan dan motivasi kepada umat Islam untuk selalu
mempelajari khazanah ilmu pengetahuan Islam yang luas, terutama dalam studi ulumul
hadis, sehingga terwujudlah masyarakat Islam yang moderat dan selalu memprioritaskan 
kehati-hatian dan klarifikasi dalam menerima dan menyebarkan berita dan informasi di era digital ini. Jenis penelitian ini termasuk penelitian kualitatif, dan sumber utamanya adalah prinsip-prinsip buku hadits ulumul yang membahas tentang hadits maudhu. Selain itu, sumber sekundernya adalah informasi yang terkandung dalam jurnal, situs web, dan lainnya. Penelitian ini menggunakan pendekatan analisis isi. Metode ini digunakan untuk menyimpulkan upaya memunculkan karakteristik pesan yang dilakukan secara objektif dan sistematis.

Kata Kunci: Hadith Maudhū, Information Management, Digital Era

\section{Introduction}

Recently, information technology and communication have massively developed in any spheres and those are enhanced by its users, derived evenly from various ages and professions. According to data, collectively obtained from numerous websites, it is found that the world's Internet users were comprised of 132.7 million people of Indonesia or $40 \%$ of 256,2 million people of Indonesia were active users of social media in 2016. This number increased $51,8 \%$ from 2014 , of which 88 million people did only connect to the internet or were user of social media. While, based on a survey of Brandwatch 2016, it has gained fact and statistic of social media of 7,3 billion people globally per July 2015 that there were 3,7 billion users of internet, 2,3 billion people were active user of social media, having averagely 5 accounts of social media, the users of social media in 2016 folded as many as 176 million people, and there were 1 million users of social media per day, averagely equal with 12 people. ${ }^{1}$

Both accelerating and advanced processes of information disclosing make everyone easily to obtain and produce any information, which it apparently not only provide adverse effect, but also give beneficial impact for human life, specifically in receiving, perceiving and managing such information. Social media is expectedly to bring advantage in socializing and interacting by distributing positive contents, yet some parties misuse it in promoting false information, or negative content. Such information broadcasted is inaccurate, exaggerated, and unclear information, and it seemingly takes from one side only, which is significantly contradicted with journalistic principle in publishing balanced information (cover both sides). Any information containing negative contents is hoax, or untrue information, using highly provocative title to drag readers and receivers to express negative opinion. Various hoaxes of information can produce hate, anger, and dispute in wider society. In addition, negative opinion, defamation, hate-speech received and attacking any party or

1 M. Ravii Marwan, "Analisis Penyebaran Berita Hoax di Indonesia," Universitas Gunadarma: Depok, 2016. 
making people becoming afraid, threatened may harm such party, so that it can insult his or her reputation and cause material loss. ${ }^{2}$

Hoax, typically, is not a brand-new thing in Islam. Whereas it is viewed from one of Islamic studies, for example hadith, there are studies discussing on hoax, such as hadith maudhu, or an intentionally fabricated hadith. This study tries to discuss correlation of the study of hadith maudh $\bar{u}$ with booming issues of hoax today. Both have similar indicators, motives, and solutions method. This study, further, attempts to contextualize a study of hadith maudhu in receiving and managing any information or news massively circulated. ${ }^{3}$

\section{Literature Review}

Any research on hadith maudhū also deals with information management having been largely analyzed and reviewed by researchers, either in the form of undergraduate papers, theses, dissertations, or journals. Nonetheless, this research is definitely different from previous researches in some respects. Thus, as comparison for this research currently being discussed, some scientific works are presented as follows:

Journal entitled "Hadis Maudhū dan Akibatnya" was written by Rabiatul Aslamiyah in the Jurnal Al-Hiwār, Vol 4 No 6 Tahun 2017. This focused on theory of Maudhu hadith and its impacts.

Journal entitled "Hadis Maudhū dan Hukum Mengamalkannya" was written by Edi Kuswadi in the Jurnal El-Banāt, Vol 6 No 1 Tahun 2016. It highlighted a review on theory of Maudhū and its applicable law.

Journal entitled "Diskursus Tentang Tipologi Hadis Dalam Kehidupan Masyarakat" (Studi Analisis Terhadap Keberadaan Hadits Maudhū) was written by Abd Majid in the Jurnal Al-Mu'āshirah, Vol 14 No 2 Tahun 2018. This work analyzed a review on hadith maudhū and its correlation with discourse of hadith typology in public life.

The similar point of this research and those three works mentioned above is the study of hadith maudhu', but the significantly contrasting point is that this research focuses on contextualize of hadith maudhu'in receiving and managing information easily circulated lately.

2 Reni Juliani, "Media Sosial Ramah Sosial Vs Hoax," At-Tan₹ir: Jumal Ilmiah Prodi Komunikasi Penyiaran Islam, 2017, 136-149.

${ }^{3}$ Abdessamad Belhaj, "The Sunna and Its Status in Islamic Law: The Search for a Sound Hadith," Islam and Christian-Muslim Relations 28, no. 3 (3 Juli 2017): 401-2, https://doi.org/10.1080/09596410.2017.1320029. 
Beside discussion on hadith maudhū, the researcher also attempts to seek for several researches focusing their study on information management, study of hoax, and like, which are as follows:

Journal entitled "Kitab Suci dan Hoax: Pandangan Alquran dalam Menyikapi Berita Bohong" was written by Luthfi Maulana in the Jurnal Ilmiah Agama dan Sosial Budaya, Vol 2 No 2 Tahun 2017. This study focused on study of the Koran's view on hoax.

Journal entitled "Kejahatan dalam Teknologi Informasi dan Komunikasi" was written by Dodo Zainal Abidin in the Jurnal Processor, Vol 10 No 2 Tahun 2017. This tried to disclose forms of crime frequently happened in information technology and communication.

Journal entitled "Kebijakan Pemerintah Menangkal Penyebaran Berita Palsu atau 'Hoax"' was written by Kurniawan Hari Saswoko in the Jurnal Muara Ilmu Sosial, Humaniora dan Seni, Vol 1 No 1 Tahun 2017. It emphasized on study of efforts and policies of government in minimizing and preventing distribution of hoax publicly.

\section{Methodology}

This research included in qualitative research concentrating on library research by analytical-descriptive based on text study. Specifically, the researcher took primary data derived from books of ulumul hadith-science of hadithdiscussing on theme of hadith maudhū. Meanwhile, the secondary data ware numerous sources derived from books, journals, and researches discoursing on information management and studies of hoax.

Practically, the data ware collected by using documentation method. It was utilized to seek for library data, comprising of written document in several literatures or books reviewing on theme of hadith maudhū, including data obtained from books, journals, or researches discussing on information management and studies of hoax.

In analyzing data, then, the researcher used qualitative analysis by using content analysis method. This method was used to make conclusion through arising message characteristic performed objectively and systematically.

For details, the first step was that the researcher presented numerous opinions of ulema on definition, history, motive, determining factor, characteristics, or indicators from the rising of hadith maudhū. Later, the researcher tried to look similarity between hadith maudhū with hoax in either concept, definition, motive, determining factor, characteristic or indicator the rising of hoax, and the last part was that the researcher tried to contextualize studies of hadith maudhu' with hoax, especially in prevention or remedy aspect. 


\section{Definition of Maudhu' Hadith and Hoax}

Epistemology, maudhu' is isim maf'ul (object) of the word wadha'a, meaning something that is made or positioned ${ }^{4}$. Meanwhile, according the term of mubaddisin, hadith maudhu' is:

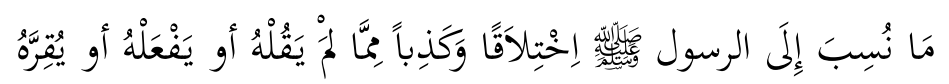

Something upon which is manipulatively and falsely relied to any words of the Prophet Mohammad shallallabu 'alaibi wasallam, whom, contrastingly, he never dictates, conducts, or states $^{5}$.

Based on above definition, we can sum up that hadith maudhu' is anything (memoir) relied heavily on the Prophet Muhammad PBUH, either his actions, words, or taqrir manipulatively or intentionally made and it is by design or lied. Firmly, hadith maudhu' is hadith-by design or made up hadith ${ }^{6}$.

Definitely, this kind of hadith totally misleads and is unacceptable without exception, since it is not hadith and this act can be deemed as falsehood against the Prophet Muhammad saw, which the doers are threatened by hell. In addition, this hadith is haram or illegal to be preached to public, excluding limited only providing explanation and example of hadith maudhu' (false) ${ }^{7}$.

Literally, hoax according to Oxford dictionary is "deceive somebody with a hoax." Also, hoax can be understood as "deceive someone by making them believe something which has been maliciously or mischievously fabricated". Structurally, hoax as noun is "trick played on somebody for a joke" or "anything deliberately intended to deceive or trick". In addition, viewed from Bahasa, hoax is an absorbed word, having similar definition with "false news" 8.

Another definition mentions that hoax is any attempt to deceit or manipulate readers/listeners to believe in something, yet the creator of false news knows that such news is fake. One example of the most common false news is claiming any goods or events with any calling differed from such real goods or events 9. Hoax spreading is one of the popular social media strategies

${ }^{4}$ Ibnu Mandzur, Lisan al-'Arab (Beirut: Daar as-Shadir, t.t.).

5 'Ajjaj Al-Khatib, Ushul Al-Hadits Ulumubu wa Musthalahubu (Beirut: Darul Fikr, 2016).

${ }^{6}$ Rabiatul Aslamiah, "Hadis Maudhu dan Akibatnya," Al-Hiwar: Jurnal Ilmu dan Teknik Dakwah 4, no. 6 (2017).

${ }^{7}$ Aslamiah.

${ }^{8}$ Luthfi Maulana, "Kitab Suci dan Hoax: Pandangan Alquran dalam Menyikapi Berita Bohong," Wawasan: Jurnal Ilmiah Agama dan Sosial Budaya 2, no. 2 (2017): 209-222.

${ }^{9}$ Dedi Rianto Rahadi, "Perilaku pengguna dan informasi hoax di media sosial," Jurnal Manajemen dan Kewirausahaan 5, no. 1 (2017). 
adopted by various advocacy groups. Hoaxes refer to "deceptive alerts designed to undermine the public's confidence in an organization, product, service, or person. Hoaxes are generally associated with powerful individuals or groups who are suspected of secretly plotting to accomplish some unjust goal. Activists create hoaxes, which often capitalize on existing conspiracy theories, by tailoring a message to justify their activities or to bring attention to issues they advocate. Past research found hoax spreading was useful in stimulating the non-public because it legitimizes the activists' claims.10

If it is seen from definition of hadith maudhu' and hoax as previously mentioned, we can come to similarity of both, false news or false information. Whereas, hadith maudhu' is any false news made by someone and it is heavily relied on the words of the Prophet Muhammad saw, hoax is any false news made by someone and it is relied on others, as if he or she has said or conducted.

\section{Determining Factors and Motives on the Emergence of Hadith Maudh $\bar{u}$ ' and Hoax}

In this discussion, the researcher presents some determining factors and motives on the emergence of hadith maudhu' and, next, the researcher attempts to contextualize it with determining factors and motives of the development of hoax. Specifically, there are some factors and motives causing the emergence of hadith maudhu', as hereunder:

First, there was political conflict in the post-death of Utsman Bin Affan Khalīfah (leadership). It occurred between Moslem as Utsman Bin Affan was killed by rebels and its leadership (khalifah) was replaced by Ali bin Abi Thalib. At that time, Moslems ware divided into several group; some demanded revenge for the death of Utsman and others supported the leadership of Sayyidina Ali (Shite). After the Siffin War, there ware other groups, namely Khawarij and supporters of Muawwiyah ${ }^{11}$.

Of those groups, demanding their own interest, they made false hadith. The first and largest making hadith maudhu' was Shite and Rafidhah. The Shite made hadith maudhu' concerning on prominent roles of Ali and Abl al-Bayt-the family of the Prophet Muhammad saw. Moreover, they made hadith mandhu' for the purpose to defame and insult Abu Bakar r.a. and Umar r.a. ${ }^{12}$.

\footnotetext{
${ }^{10}$ Keonyoung Park dan Hyejoon Rim, "Social media hoaxes, political ideology, and the role of issue confidence," Telematics and Informatics 36 (1 Maret 2019): 1-11, https://doi.org/10.1016/j.tele.2018.11.001.

${ }_{11}$ Al-Khatib, Ushul Al-Hadits Ulumuhu wa Musthalabubu.

12 Hasbi As-Shiddieqy, Sejarab dan Pengantar Ilmu Hadis (Jakarta: Bulan Bintang, 1978).
} 
Second, there was fanaticism of schools of thought, madzhab. This fanatism was occurred in the post-defamation, which was the assassination of Utsman Bin Affan r.a, and the Shite was a group that was responsible in making lies mostly. Imam Malik, asked about such group, said, "Do not ask them to discuss and do not memorize from them since they are liar." An example of false hadith made by them was: "I, myself, (Muhammad) is a weight of science, and Ali is its weighted disc, Hasan and Husain are its strings, Fatimah is the hook, and imams, Islam priests, is the pole to weight deeds of those who loves us and those who hates us."

Besides the Shite, another group who was the most counterfeiting hadith was the Khawarij, mainly on prominent roles of Mu'awiyah r.a. Also, the fanatic followers of figh, Islamic jurisprudence, made false hadiths to affirm their madzhab ${ }^{13}$.

Third, there was tendency of over-praying. As mentioned earlier about fanatism of madzhab, emerging of new groups, another factor was the poets, story-tellers, intentionally gaining benefit by making false hadith attributed (nisbah) to the Prophet Muhammad saw on significances of over-praying, as an example;

$$
\text { من قال لا إله إلا الله يخلق من كل كلمة منها طائر منقاره من ذهب وريشه من مرجان }
$$

"Whomsoever utters the word Laa Ilaaha illa Allab (There shall no God other than Allah), bence Allah shall create from such word a bird whose beak. is from gold and its feather is from marjan (actinozoan)."

One of them was Maisarah bin Abdu Rabbih. As he asked, "From where do you get such hadiths? "He answered, "I counterfeit it to amuse people" 14.

Fourth, it was purposed to amuse or bootlick the ruler. This was done to get position, reward, or other material facilities by overpraising or by means of seeking for affirmation against the ruler's action to amuse and clam the ruler's mood. One of narrator groups was Ghiyats bin Ibrahim coming to appear before al-Mahdi, a leader (khalifah) loving doves and playing with them. When a dove came in front of him, Ghiyats spontaneously made hadith attributed to the Prophet Muhammad saw;

$$
\text { لا سبق إلا في نصل أو خف أو حافر أو جناح }
$$

"None of competition excludes on spear, camel race, horse race and dove race."

${ }^{13}$ Manna' Al-Qaththan, Pengantar Studi Ilmu Hadis (Jakarta: Pustaka Kausar, 2017).

14 Al-Qaththan. 
Ghiyats added the word أو جناح in such hadith by purpose to show that what such al-Mahdi (khalifah) did was based on hadith of the Prophet Muhammad saw. As result, al-Mahdi gave him 10.000 dirham 15.

After analyzing those four determining factors of the emergence of hadith maudhu', we then try to contextualize them with causing factors of the development of hoax. First; existence of political conflict resulting the emergence of false hadiths becomes one of significant factors causing hoax circulation. A conflict happened between government and opposers, specially approaching general election, either presidential or member of legislative, sometimes triggers any spread of hoaxes or misleading and invalid information. Ministry of Communication and Informatics of the Republic of Indonesia has identified approximately 62 hoax contents related to the 2019 general election. It can be seen from website www.news.detik.com dated on 2nd January 2019, Wednesday. Ad-interim officer Head of Public Relation Bureau of Ministry of Communication and Informatic, Ferdinandus Setu, said that this result was based on investigation using AIS machine by Sub-directorate of Content Controlling on Internet, Directorate of Controlling, and Directorate General of Informatics Application. As result, Ministry of Communication and Informatics has released information regarding clarification and content indicated as hoax through official website www.kominfo.go.id and stophoax.id.

Second; Fanatism of madzhab and ideology, similarly, becomes triggering factor of the emergence of false news. In the context of recent Indonesian politic, fanatism against one of political parties or one of presidential or vice-presidential candidates is able to weaken rational and logic, and it, later, gives impact on political identity. However, in Indonesia, the emergence of political identity within political dynamic is varied, yet it correlates with injustice and united in right claimed by each group or certain social classes. Hence, a different, becoming a significant benchmarking of diversity existing in Indonesia, turns political identity as affirmation of such different in Indonesia. Negligence of conflict underlaind by a diverse political identity will create state's instability. Any identity similarity-based political identity often is causing factor of arising political conflict, mainly related to tension between superior versus inferior group, or majority versus minority 16.

Furthermore, from above factors, hoax occurs since there are several following factors; First, provocative and interesting news article becomes viral in social media. Consequently, it can attract advertisement and news providers to gain abundant income through their original site. Apparently, it seems as main

\footnotetext{
${ }^{15}$ Nuruddin 'Itr, Ulumul Hadits (Bandung: Remaja Rosdakarya, 2016).

${ }^{16}$ Yeni Sri Lestari, "Politik Identitas Di Indonesia: Antara Nasionalisme Dan Agama," Journal of Politics and Policy 1, no. 1 (2018): 19-30.
} 
factor for most producers in gaining benefits from the existence of hoax, intentionally and purposively made and designed. Second, there is troublesome of decreasing popularity and reputation of certain mass media. Consequently, mass media presents mind-blowing and exaggerating false news, or hoax, as a means of boosting up such reputation. Third, social media turns like double sides of coin. On one side, it is a means of modern communication, and, on another side, it provides as money machine by presenting sensational and dramatic news and selling appeal of social media, then, will produce more profits. Fourth, the extent of trust in industrial media is decreasing continuously, so presenting hoax is one of alternatives to gain more popular appeal 17.

Hoaxes are straightforwardly circulated in society since, today, people can own simply cheap and modern communication tool, specifically in the using of smartphone as media of information searching. Moreover, society is easy to be provoked with obscure issues without firstly verifying or confirming the truth of such information or news, so that they directly forward such obscure information. Additionally, literacy culture is undoubtfully still low among our people, so, subsequently, there is a trend in discussing any news without based on accurate data and only relying on memory and unclear source ${ }^{18}$.

\section{Prevention of Hadith Maudh $\bar{u}$ ' and Hoax}

The ulemas have taken some better cautions in eradicating and combating counterfeiters of hadiths and tried to prevent and avoid any harm resulted from those fraudsters. For such, they have used various efficient ways as follows: First, understanding and identifying indicators of false hadiths, such as contradictive content against with common sense, or contradicted with logic and reality, or against with firmly and clearly religious provisions, or weak or disorganized structure of lafazh, that is a series of several letters forming certain meaning, or any indication of such narrator showing his or her deceit. In example, a narrator who is Rafidhah and his hadith contains prominent roles of Ahl al-Bayt. Second; giving strict warning to those liars and disclosing their depraved deeds, by announcing their lie to public figures. Third, analyzing characteristics of narrators by observing their attitude and track record and tracking down the citations used to verify whether hadith is legitimate or not (sanad). Therefore, they do not receive any hadith not having sanad, and they deed such hadith as haram hadith. Fourth, examining the truth of hadith by

${ }^{17}$ Maulana, "Kitab Suci dan Hoax."

${ }^{18}$ Nasrul Chaqiqi, "Kontekstualisasi sikap Nabi Ya'kub terhadap berita hoax di era modern: telaah penafsiran surat yusuf (12): 16-18” (PhD Thesis, UIN Sunan Ampel Surabaya, 2018). 
comparing with memoir through other paths and acknowledged and valid hadith. Fifth, arranging a compilation book of hadith maudhu' to give illumination and warning to society on the existence of such hadiths 19.

In detail, reflected from five prevention steps of hadith maudhu' previously having been stated above, there are several relevant and efforts and it is able to be contextualized in terms of preventing hoax, as follows:

First, in understanding hoax, public should necessarily be educated in order to be able consciously identifying any hoaxes recently widely circulated in internet by following characteristics, such as coming from unreliable site, no date of events, obscure location of event, mostly containing weird contents and frontally and strictly cornering certain party, unbalanced news and expressing one-sided fact or consideration, illogic and rare plot and content, contradictive and unparallel language and sentence structure, using emotional and provocative language's tone. This first step, if viewed, has likely similarity with prevention step of hadith maudhu', identifying indicators of hadith maudhu' such as contradictive content against with common sense, or contradicted with logic and reality, or against with firmly and clearly religious provisions, or weak or disorganized structure of lafazh.

Second, it should design regulation and stating sanction or fine for those distributing and making hoax. In this case, the government of Indonesia has made and drafted laws related to such issue. The role of government in eradicating and tackling down hoax circulation is stated in several articles, such as Criminal Code, Laws No. 11 of 2008 on Information and Electronic Transaction (ITE), Laws No.40 of 2008 on Elimination of Race and Ethnic Discrimination. Further, any actor of spreading hoaxes can be charged with article related to hate speech having been regulated in other Criminal Code and Laws outside of Criminal Code. On January 2017, the Government blocked 11 sites containing negative contents, but this action never ended up in court. However, judicially, total of hoax propagators is not equal with total of trials since it has not been able to seize several hoax propagators and government's action, unfortunately, is just blocking hoax sites. While, producers of hoax can still produce by promoting threat and expanding their coverage. More developing hoaxes in society boost some parties in fighting against hoax distribution. Since 2016, Facebook has already introduced feature enabling a link of article shared through Facebook that will be given mark as "dispute" (against with) for those articles allegedly distributing doubtful information. Popular instant messaging applications, namely Line, also combat hoax by actively circulating information through Line New where any hoax is heatedly discussed in public. Besides platform of social media, public also initiate program of Turn

19 'Itr, Ulumul Hadits. 
Back Hoax, which one hoax can be identified and published concerning on its authenticity via various medias, such as Facebook's group and official website of Turn Back Hoax 20.

In addition, the Police Department of the Republic Indonesia, with same spirit, has also taken some strategic precautions as prevention and remedy step on hoaxes. There are at least three steps taken, as follows: First, it is pre-emtive, preliminary actions performed by police department to prevent crime action. Attempts having been done in remedy any crime using pre-emtive are cultivating good values/norms crystalized into oneself to prevent in doing crime-this prevention is derived from theory of NKK (Intention + Opportunity $=$ Crime). If those good values/norms have been well-crystalized, it can dismiss intention doing crime action; though there is opportunity. The pre-emtive done by police in remedy criminal act of hoax propagators is by socialization through social media. Second, it is preventive, comprising of follow up activity of the pre-emtive which is in prevention level prior to any crime happened. The stressing point of this step is erasing any opportunity to commit crime actions. Some preventive actions having been done by police in remedy crime action committed by hoax propagators are forming Force Task of Cyber Patrol, assigned to supervise Information Technology and Social Media. Third, it is repressive, any action performed responding any crime action happened and law enforcing by giving a sentence. The repressive is one of attempts in remedy crime conceptionally taken after any crime action taken place. This remedy is aimed to respond actors of crime in accordance with their action and give awareness that their action is against the laws and harms public so that it can give multiplier effects to others as well. Repressive done police in remedy crime action of hoax propagators is law enforcing against hoax propagators ${ }^{21}$

\section{Effects of Hadith Maudh $\bar{u}$ ' and Hoax Distribution}

Any wide-spreading either hadith maudhu' or hoax, indeed, has some effects for public life. These effects rising out because of hadith maudhu' are: Firstly, it results and sharpens dispute among Moslem. One mazhab/group being attacked by other groups/parties by using false hadith will naturally defense and maintain its group, and, even, it will take offensive stand against other attacking groups by making similar false hadith. Subsequently, there will be a battle and mutually degenerating. It, then, causes a heated dispute between Moslem. This heated dispute, off course, will weaken unity of Moslem and it

\footnotetext{
${ }^{20}$ Rahadi, "Perilaku pengguna dan informasi hoax di media sosial."

${ }^{21}$ Dona Raisa Monica, "Upaya Kepolisian Dalam Penanggulangan Tindak Pidana Penyebaran Hoax," Jurnal Poenale 5, no. 2 (2018).
} 
will result on disintegration. Secondly, the emergence of hadith maudhu' is sometimes against with common sense, correct logic and existing facts, and it can insult reputation of the Prophet Muhammad saw. Making any expression and heavily relying on the Prophet Muhammad saw are a huge mistake and highly dangerous. The impacts can endanger him or herself and others as well. The Prophet Muhammad saw firmly warned to those who dared to lie against him as stated in his speech: "Whomsoever intentionally lies against me, he or she shall be in agony" (Shahih Bukhari. Verse I h.38). Third, Obscuring understanding on Islam is forbidden, as it is previously mentioned that the source of Islam after the Koran is Al-Hadith of the Prophet Muhammad saw. Indeed, Islamic values becoming guidance for Moslem are mostly and largely sourced from $\mathrm{Al}$ Hadith. If hadith becoming source of false, different and contradicted with Islam, there will be misunderstanding on Islam. Then, Islam will be not acknowledged since Islam comes to Moslem as holy religion that can lead and bring humankind into prosperity and welfare in the world and life after death. This result can be seen currently that Islamic society does not fully use Islam as their way of life, since they do not believe totally in Islam. Any group outside of Islam willingly learning Islam will lessen their intention for they get misleading information of Islam derived from false source, or they will probably underestimate and mock Islam as Islam is illogic and unreasonable because of contradicting with existing data and facts 22 .

Similar with hadith maudhu', hoax also brings significantly adverse effects in human life, such as giving loss to society for hoaxes contains a huge fraud and defamation; disintegrating public, either on behalf of political interest or religious organization; and negatively influencing public opinion as hoax becomes provocateur to degrade society. In addition, hoaxes are intentionally and purposely made for the purpose to discredit one party, so that it can result on divide et impera among Moslem. It is deliberately aimed to uproar and provoke public, so that it creates fear among society. ${ }^{23}$

\section{Conclusion}

From above review, as conclusion, it can be summarized that studies on the concept of hadith maudhu' are always relevant to be reviewed and contextualized by recent life condition in receiving, perceiving, and managing any information circulated in public. Virally wide-spreading hoax in social media is a significantly restless phenomenon in society widely. It has given significantly adverse impacts, such as designing public opinion as lie, divide et impera between Moslem, mind-provocation, and losing Moslem. Therefore,

\footnotetext{
22 Aslamiah, "Hadis Maudhu dan Akibatnya."

${ }^{23}$ Maulana, "Kitab Suci dan Hoax."
} 
revitalization on the study of ulumul hadith, specially related to hoax, is a worthy step to remedy hoax circulation, which both have more in common, either its definition, motive, indicators, and effort to prevent and remedy.

\section{Bibliography}

Al-Khatib, 'Ajjaj. Ushul Al-Hadits Ulumubu wa Musthalabubu. Beirut: Darul Fikr, 2016.

Al-Qaththan, Manna'. Pengantar Studi Ilmu Hadis. Jakarta: Pustaka Kausar, 2017.

Aslamiah, Rabiatul. "Hadis Maudhu dan Akibatnya." Al-Hiwar: Jurnal Ilmu dan Teknik Dakwah 4, no. 6 (2017).

As-Shiddieqy, Hasbi. Sejarah dan Pengantar Ilmu Hadis. Jakarta: Bulan Bintang, 1978.

Belhaj, Abdessamad. "The Sunna and Its Status in Islamic Law: The Search for a Sound Hadith." Islam and Christian-Muslim Relations 28, no. 3 (3 Juli 2017): 401-2. https://doi.org/10.1080/09596410.2017.1320029.

Chaqiqi, Nasrul. “Kontekstualisasi sikap Nabi Ya'kub terhadap berita hoax di era modern: telaah penafsiran surat yusuf (12): 16-18.” PhD Thesis, UIN Sunan Ampel Surabaya, 2018.

'Itr, Nuruddin. Ulumul Hadits. Bandung: Remaja Rosdakarya, 2016.

Juliani, Reni. "Media Sosial Ramah Sosial Vs Hoax." At-Tanzir: Jurnal Ilmiah Prodi Komunikasi Penyiaran Islam, 2017, 136-149.

Lestari, Yeni Sri. "Politik Identitas Di Indonesia: Antara Nasionalisme Dan Agama." Journal of Politics and Policy 1, no. 1 (2018): 19-30.

Mandzur, Ibnu. Lisan al-'Arab. Beirut: Daar as-Shadir, t.t.

Marwan, M. Ravii. "Analisis Penyebaran Berita Hoax di Indonesia." Universitas Gunadarma: Depok, 2016.

Maulana, Luthfi. "Kitab Suci dan Hoax: Pandangan Alquran dalam Menyikapi Berita Bohong." Wawasan: Jumal Ilmiah Agama dan Sosial Budaya 2, no. 2 (2017): 209-222.

Monica, Dona Raisa. "Upaya Kepolisian Dalam Penanggulangan Tindak Pidana Penyebaran Hoax." Jurnal Poenale 5, no. 2 (2018).

Park, Keonyoung, dan Hyejoon Rim. "Social media hoaxes, political ideology, and the role of issue confidence." Telematics and Informatics 36 (1 Maret 2019): 1-11. https://doi.org/10.1016/j.tele.2018.11.001. 
198 | AL QUDS : Jurnal Studi Alquran dan Hadis vol. 3, no 2, 2019

Rahadi, Dedi Rianto. "Perilaku pengguna dan informasi hoax di media sosial." Jurnal Manajemen dan Kewirausahaan 5, no. 1 (2017). 